In these circumstances, a sub-committee of the Institution of Civil Engineers Research Committee was formed in March 1936, to investigate the existence and extent of damage due to leakage currents, to carry out research work, if necessary, and particularly to obtain mutual agreement on the conditions under which earthing connexions to metal water-pipes might be made and to try, if possible, to formulate a set of regulations. The sub-committee included nominees from the various engineering associations chiefly concerned, and Mr. H. W. Swann, senior electrical inspector of factories of the Home Office.

The sub-committee has been successful in ob. taining unanimous agreement on the conditions under which earthing connexions may be made, and has now issued its report*.

The first clause in the report is that an earth-wire connecting an electrical installation to a water-main or water-pipe is to be used only as a safety measure, for the purpose of returning to the source of supply such leakage current as may flow from the electrical installation, for radio currents, or currents from radio-interference suppression devices. In the second clause, it is forbidden to cut or drill or break a watermain or water-pipe. The third clause states that every device used must be of 'approved' design. The fourth clause states that due notice must be given to the water authority concerned when an earthconnexion is made to a buried water-pipe. The fifth clause states that wherever an earth-connexion is made to a water-main or water-pipe on any premises

- Regulations for Earthing Electrical Installations to Metal WaterPipes and Water-Mains. Pp. 6. (London: Institution of Civil Eipes and Water-Maineers, 1938.) 6d. in which a water-meter is installed, a suitable bond must be placed across it by the user, free of expense to the water authority. Finally, if the water supply authority has reason to believe that damage to water-mains or water-pipes is being caused by an excessive flow of electric current through the earthconnexion, it can ask the electricity supply authorities for the district to test the installation in the presence of a representative of the water company. The water company can, if it requires, make its own test after advising the electric supply company.

Post Office installations, other than those for power and lighting services, are specially excluded from the application of these regulations, but are subject to agreement between the authorities concerned.

In the course of its work, the sub-committee came to the conclusion that there are certain other aspects of the problem which could with advantage form the basis of research. Funds have been subscribed for this research by the interests concerned, and the investigation has been undertaken by the British Electrical and Allied Industries Research Association. The programme of research so far approved is as follows: (1) The amount and effect of aggregate leakage currents on water-pipes. (2) The possibility of partial rectification of alternating currents in underground water supply systems, (a) at earthing connexions and (b) between metal pipes and the soil. (3) The possibility of primary cell effects in water supply systems. (4) The relation of all the above to the question of corrosion. The sub-committee is to be congratulated on its very practical report.

\title{
Social Science at Liverpool
}

\section{$\mathrm{T}$} HE publications of the Statistics Division of the Social Science Department of the University of Liverpool provide an admirable illustration of the valuable work which the universities can undertake in the field of social science. The latest addition to the New Merseyside Series ("Handbook of Social Statistics Relating to Merseyside" : University Press of Liverpool. 1s. net) is no exception and indeed in some matters indicates a further function or responsibility of the university which undertakes such local studies-that of educating local opinion to secure requisite action on the facts disclosed.

This responsibility is very clearly implied in the opening section of this handbook, in which Mr. D. Caradog Jones directs attention to the marked tendency for the population of all four Merseyside boroughs to decline. The rate of natural increase in Liverpool is already less than one half the increase in the early years of the present century, and the rate of increase in Birkenhead is only one quarter of what it then was. He asks the pertinent question whether the serious effect of the anticipated decline upon the demand for houses, for schools, for transport, and upon the need for social services, has been fully appreciated by the local authorities, and, if or whether they are taking steps to deal with a situation that is likely to change rapidly.

In the face of these facts, local authorities will bear a heavy responsibility if on the contrary they continue to legislate on the assumption that the talk about fall in numbers does not concern them, or that if it does there will be plenty of time to set their house in order when the fall begins to take place. None the less, having disclosed the true situation, scientific workers have some measure of responsibility for seeing that the facts are brought to the notice of those concerned with action in a sufficient, definite and convincing manner.

It would not be easy to improve on the lucid but brief presentation which Mr. Caradog Jones uses in this handbook. The section on trade gives an analysis of the trade of the Port of Liverpool in comparison with that of London and the next three most important ports of the United Kingdom. Liverpool showed a greater relative improvement than London in 1936 as compared with 1932 in the value of goods imported, but for exports the position is reversed. Cotton, imported raw and exported as manufactured textiles, holds an outstanding place in the trade of Liverpool and the figures indicated an appreciable increase between 1932 and 1936 in the home demand for manufactured cotton textiles as well as of woollen manufactures.

Statistics of employment alone at first suggest that the position on Merseyside is not discouraging. Actually Merseyside found employment in 1937 for 13,000 more insured workers than in 1929, which is generally regarded as the best all-round post-War 
year. This figure, however, represents an increase of only 4 per cent as compared with a 12 per cent increase in Great Britain as a whole, and a 38 per cent increase in unemployment on Merseyside as compared with 16 per cent in Great Britain. Moreover, although the high level of unemployment on Merseyside has not altered very much in the last twelve months, the August figures indicating an increase of less than 2 per cent, the cost of its relief has increased. Unemployment insurance payments in August 1938 were nearly a fifth greater than in August 1937, while unemployment allowances were more than 5 per cent less. Although this position is due partly to the increases in benefit made this year by the Beveridge Committee and the fall in the cost of the means test, to long-standing cases getting work, to final 'cuts' under the 'Standstill Act', and to the revised system of relieving casual labour, the fact that the means test is costing less and benefit more, while unemployment remains much the same, is unexpected.

The cost of outdoor relief decreased between June 1937 and June 1938, but able-bodied unemployed still cost the ratepayers of Merseyside $£ 38,000$ a month, $£ 6,200$ of which goes to insured workers. Mr. Caradog Jones refers once more to an unfortunate gap in the social services. If an insured person falls sick, he ceases to qualify either for unemployment benefit or for unemployment allowance ; he is entitled to sickness benefit, but this takes no account of dependants, and he is therefore frequently driven to apply for poor relief. This is an additional trial to the mind when the body is least able to stand it. Mr. Jones also refers to the absence of anything but poor relief for non-manual workers, such as ships' officers, salesmen and clerical workers who when in work were earning more than $£ 250$ a year.

A section on education indicates the difficulties which many teachers in elementary schools in the area have to face as well as the points at which reorganization on the lines of the policy laid down in the Hadow report is most backward. The housing situation is summarized in a further section and particulars of rents and rates are analysed in a final table. The whole handbook, brief as it is, affords an admirable example of the presentation of facts in a manner designed to stimulate appropriate action.

\section{The Highgate Literary and Scientific Institution Centenary Celebration}

$\mathrm{O}^{\mathrm{N}}$ $\mathrm{NE}$ of the marked features of the intellectual life of the early years of the nineteenth century was the founding of philosophical, literary or scientific institutions, or societies where lectures could be delivered, discussions held and where libraries could be formed and housed. Many of these institutions, especially those in small towns, have disappeared, or parts of their activities have been absorbed either in the local free library, or in the neighbouring technical college.

Some of the societies have survived and are doing most useful work : amongst these may be mentioned the Cambridge Philosophical Society, the Royal Glasgow Philosophical Society, the Manchester Literary and Philosophical Society, the Leeds Philosophical Society, and the Highgate Literary and Scientific Institution, which has just celebrated its centenary.

Exactly one hundred years ago, on January 16, 1839, a meeting was held at the Gate House Tavern, Highgate, to consider the formation of a society, or, in the quaint words of the invitation card, "for the purpose of forming an Institution designed to excite and cultivate an intelligent interest in the objects of literature and science". The first president was Mr. Harry Chester, who served in that capacity for eighteen years. The Society was evidently welcomed by the inhabitants of Highgate, because at the end of a month the president in his first presidential address was able to state that 110 members and associates had been elected, and that four hundred volumes had been placed in the library, of which three hundred were donations.

The founders were determined that the Institution should be democratic, as is shown by the opening remarks of the president: "This is a voluntary Association of many for the benefit of all and open to all; it is no exclusive Association, to which admission depends on the likes and dislikes of indiv. iduals. Here all classes may meet without annoyance to any : and therefore with advantage to all."

In May 1840, the premises the Institution still occupies were rented from the trustees of the estate of Sir John Hawkins, who was an executor, and also a biographer, of Dr. Samuel Johnson. In 1932 it was found possible to purchase the freehold of the property, and in 1936 that of the immediately adjoining property, thus giving the opportunity for further future extensions.

The annual reports of the committee of management of the Institution give a brief story of its activities. In the seventh report (unfortunately, the first six reports are missing) a list of the periodicals in the reading room for the year 1846 is given. It is interesting to note that Blackwood's, Chambers's Journal, the Edinburgh Review and the Quarterly Review were mentioned; the remaining periodicals are no longer in existence.

The formation and maintenance of the library has always been regarded as one of the chief duties of the committee of management. The library now consists of more than 11,000 volumes, and includes $\mathbf{a}$ con. siderable number of books of reference. It must be confessed that the scientific side of the library has been allowed to lapse more than it should have done.

The giving of lectures by well-known experts and authorities has always formed an important activity of the Institution. It has been estimated that some 1,700 lectures on the greatest variety of subjects have been given during the past century. Looking back through the annual reports, the development of many of the sciences can be traced by the names of the lecturers and their subjects. "The Proposed Atlantic 